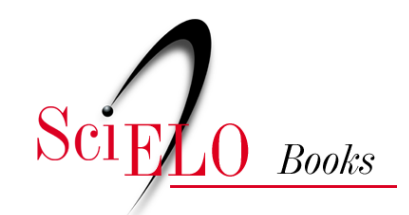

1. O território da perspectiva da economia fluminense: dimensões da crise financeira

\title{
A crise no estado do Rio de Janeiro entendida não apenas como uma questão financeira
}

\author{
Bruno Leonardo Barth Sobral
}

\section{SciELO Books / SciELO Livros / SciELO Libros}

SOBRAL, B.L.B. A crise no estado do Rio de Janeiro entendida não apenas como uma questão financeira. In: PENALVA, A., CORREIA, A.F., MARAFON, G.J., and SANT'ANNA, M.J.G., eds. Rio de Janeiro: uma abordagem dialógica sobre o território fluminense [online]. Rio de Janeiro: EdUERJ, 2018, pp. 34-62. ISBN 978-85-7511-476-6. https://doi.org/10.7476/9788575115169.0003.

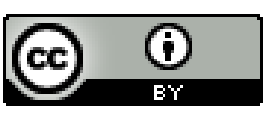

All the contents of this work, except where otherwise noted, is licensed under a Creative Commons Attribution 4.0 International license.

Todo o conteúdo deste trabalho, exceto quando houver ressalva, é publicado sob a licença Creative Commons Atribição $\underline{4.0}$.

Todo el contenido de esta obra, excepto donde se indique lo contrario, está bajo licencia de la licencia $\underline{\text { Creative Commons }}$ $\underline{\text { Reconocimento 4.0. }}$. 


\section{A crise no estado do Rio de Janeiro entendida não apenas como uma questão financeira}

Bruno Leonardo Barth Sobral

\section{Introduçáo}

Há uma variável que não controlamos, que é a retomada da economia. Fizemos cenários muito conservadores. Estamos considerando sair das dificuldades sem projetar uma retomada (Áureo, 2017, n.p.).

Nos últimos anos, o governo do estado do Rio de Janeiro veio passando por uma progressiva deterioração de suas contas. A situação se tornou tão dramática que não apenas o governo se viu impedido de executar plenamente as políticas públicas, como também ficou gravemente insolvente a ponto de sofrer sucessivos arrestos judiciais. O resultado foi a explicitação de uma situação de claro desgoverno, no qual os gestores já tinham perdido a capacidade de planejamento na execução orçamentária. Assim, o rumo da gestão passou a ser guiado pelas tentativas de renegociação de sua dívida somadas às disputas de inúmeros grupos de pressão que foram afetados.

Contudo, a problemática da crise financeira do governo estadual não é simplesmente o ajuste das contas públicas, mas o procedimento adotado dentro de um processo de recuperação econômica sustentado. No presente capítulo, defende-se que o ajuste fiscal não é um pressuposto. A preocupação principal deve ser garantir a recuperação da economia, logo, evitar que o ajuste das contas públicas prejudique esse processo de retomada.

Além dessa introdução e da conclusão, o texto tem três seções. Na primeira, será feita uma crítica à tese da "contração cíclica expansionista", apontando os riscos que isso traz ao se considerar que ela respalda o acordo com o governo federal. Na segunda, apresentam-se aspectos chaves desse acordo diante de uma síntese das diferentes visóes no debate sobre a problemática atual. $\mathrm{Na}$ terceira, apresenta as bases fundamentais para um diagnós- 
tico crítico, buscando questionar certas generalizaçóes ao se enfatizar as especificidades fluminenses.

\section{O mito da contraçáo fiscal expansionista e os riscos para a possibilidade de recuperaçáo econômica}

A crise não é uma exceção, um desvio ou uma anomalia. Ela é o resultado esperado da tomada de risco crescente em uma economia capitalista que explicita seu quadro de incerteza. A dinâmica do sistema náo se baseia em garantir um ambiente de normalidade por meio de ajustes e retornos a supostos pontos de equilíbrio. Ao contrário, funciona por ondas de otimismo e pessimismo, e, assim, ciclicamente a economia capitalista entra em crise. O problema é que essas ondas não são regulares, os limites e profundidade delas são indeterminados.

Myrdal (1957) tratou isso em sua crítica ao pensamento econômico ortodoxo, defendendo que a economia funciona pelo princípio da "causação cumulativa”. Logo, uma decisão autônoma e com capacidade indutora gera um mecanismo de propagação em um mesmo sentido concentrando força e poder de arrasto. Portanto, segundo essa interpretação, a economia não seria composta de um conjunto de automatismos articulados capazes de definir fundamentos (e, logo, boas práticas) de acordo com alguma noção de equilíbrio. Em vez de cada ação corresponder a uma reação que tende a provocar ajustamentos lógicos, o conjunto de açóes tem potência assimétrica e disparidade de força cumulativa.

Assim, a economia tende a ser composta de decisóes com alguma posição dominante capaz de provocar reaçóes em cadeia difíceis de ser revertidas, logo, uma dinâmica desequilibrada. Isso não é visto como uma anomalia a ser corrigida, trata-se de algo inexorável enquanto ponto de partida de mudanças estruturais recorrentes na organização dos mercados, o que define sentido à sua trajetória de longo prazo.

Da mesma forma, Hirschman (I96I) destacou que a eficiência não é um pressuposto que antecede o processo decisório. Ao contrário, ela emerge em uma dinâmica que foi capaz de perseverar a ponto de náo se abater com as eventuais tensóes conjunturais e desajustes intrínsecos à reestruturação do tecido econômico. Logo, é um resultado histórico de açóes planejadas capazes de romper inércias na organização anterior dos mercados e redefini-los sob sua 
orientação e interesses estratégicos. Ou seja, a eficiência é vista em uma noção dinâmica que reflete a capacidade política de recriar os mercados. Com isso, o autor destaca a importância da relação entre a eficácia de decisões e uma reorganizaçáo de mercados marcada pelo desenvolvimento de um sistema de encadeamentos. Quanto mais foco na criação de maior complexidade e sinergia dentro desse sistema integrado, maior o poder de irradiação e sustentação de sequência de decisóes estruturantes.

Rompendo com o individualismo metodológico, as decisóes podem ser consideradas como não existindo de forma isolada, mas sistêmica. Vistas em conjunto, elas podem ser incompatíveis umas com as outras, dependendo de um arcabouço institucional e conjuntos de políticas indutoras que permitam algum grau de coordenação política. Em vez de uma discussão de racionalidade pura, trata-se mais diretamente de estruturas de dominação e poder que definem uma lógica hierarquizada que identifica incompatibilidades e se antecipa empregando formas de mediação e rearticulação da cadeia decisória.

No momento de crise, a economia está dentro de uma onda de pessimismo imensurável que explicita os problemas de coordenação e a fragilidade do sistema de encadeamentos. Nesse cenário, o racional para os agentes individuais é não gastar ("poupar”). Contraditoriamente, não o seria para a sociedade, porque a retração econômica se torna generalizada e brutal se todos tiverem esse comportamento. De toda forma, significa um processo cumulativo de queda da renda agregada: quedas de receitas induzem novas reduçóes de gasto, e estas induzem novas quedas de receita - ou seja, é um movimento de "bola de neve". Por essa razão, a discussão do ajuste fiscal precisa estar inserida em uma discussão de como sair desse ciclo vicioso cumulativo: uma grave retração econômica porque os agentes individuais, mesmo que náo combinando explicitamente, decidem evitar gastar ao mesmo tempo.

Isso diverge da busca pelo ajuste fiscal como pré-condição para a recuperação, em particular, baseada na tese da "contração fiscal expansionista". Essa tese ganhou maior expressão à medida que encontrou base em relativo ceticismo com o potencial de políticas fiscais anticíclicas (Perotti, 2002; Mountford e Uhlig, 2005; Hall, 2009). Seu pressuposto é que cabe ao governo focar na sustentabilidade de seu endividamento e assumir regras fiscais que limitem sua discricionariedade junto a um programa duro de cortes de despesas, deixando para a política monetária o papel de regular a demanda efetiva. Giavazzi e Pagano (1990) e Alesina e Perotti (1995) defenderam que caberia ao go- 
verno sinalizar que está fazendo seu "dever de casa", abrindo-se espaço para os agentes privados reagirem e retomarem seus negócios, porque, supostamente, isso geraria efeitos positivos sobre as expectativas e favoreceria a redução da taxa de juros.

Todavia, estudos mais recentes refutam que o déficit público tende a ser superado sem qualquer política fiscal anticíclica voltada para combater a continuada queda de renda agregada, o que leva também a uma queda de arrecadação tributária. Destaca-se o artigo de Blanchard, Dell'Ariccia e Mauro (20I0), por estar no seio de um debate crítico dentro do próprio FMI. É claro que essa abertura para questionamentos não levaram a uma revisão profunda dentro do paradigma ortodoxo, muitas vezes sendo tratada como uma concessão a um período de excepcionalidade (Romer, 20I2; De Long e Summers, 2012). De toda forma, a evidência empírica a partir da pesquisa de Islam e Chowdhury (20I2) reconheceu que, em I2O casos analisados, apenas em 27 houve contração fiscal e redinamização econômica, geralmente em razão de estar acompanhada de fatores externos.

Não se deve ignorar que a arrecadação pública é pró-cíclica, ou seja, em momento de crise a arrecadaçáo diminui. O problema é que esse momento se trata exatamente do aumento da importância do gasto público. Ao se tomar o ajuste fiscal como pré-condição, geralmente combinam-se os cortes de gastos públicos e agravamento do quadro recessivo, acarretando em novas recomendaçóes de cortes. Ou seja, o problema vira uma "bola de neve" na qual se exige maior severidade contracionista do poder público com novos e maiores cortes. Chega-se ao ponto de não ter mais de onde cortar de forma significativa e sem prejuízos à normalidade operacional dos programas e instituiçóes públicas. Nessa situação limite, torna-se explícito que, ao invés de ganhos de eficiência, evidencia-se a piora na qualidade das políticas públicas com prejuízos graves à população atendida (fato ocorrido no caso fluminense).

Por isso, é importante ter cuidado para não se resumir a um viés ideológico que parta de uma visão generalista de um Estado "perdulário", no qual seria defensável que ganhos de eficiência sempre são possíveis focando na redução de seu tamanho. Blanchard e Leigh (2013) alertam que erros em processos de ajustes fiscais estavam correlacionados à subestimação do papel do gasto público. Afinal, se os agentes privados não gastarem coletivamente, tende a haver queda de renda agregada, ainda que ocorra o efeito expectacional positivo do ajuste fiscal. Os agentes privados, a partir de suas expectativas, podem aumen- 
tar a confiança, mas eles não gastam se a economia não apresentar sinais significativos de melhora. Aliás, é o que transcorreu recentemente no cenário nacional brasileiro: um descolamento entre a trajetória de confiança e a evolução do PIB e seus diversos componentes na economia real.

Evitar isso depende da análise do gasto público segundo seu efeito multiplicador, ou seja, na dinâmica econômica pode ser mais que proporcional, em particular, em um cenário recessivo. No agregado, o efeito não é apenas daquela decisão autônoma de gasto, mas induz diretamente o gasto de outros agentes como uma reação em cadeia. E vice-versa, se ele deixa de gastar, há uma retração amplificada ao inibir os gastos de outros agentes dependentes desse estímulo.

No meio de uma recessão, o efeito expectacional de um ajuste fiscal não tende necessariamente a ser positivo a ponto de neutralizar os efeitos contracionistas via multiplicador. Ou seja, a recessão pode se alongar e até se aprofundar. Pires (20I7) ponderou que uma contração fiscal tende a algum sucesso quando a economia possui válvulas de escape para alternativas de crescimento, por exemplo, expansão do setor externo ou política monetária expansionista. O mesmo autor alertou que o ativismo fiscal tem limites diante do nível da dívida pública e os efeitos que produz nos prêmios de risco e no grau de volatilidade característico de economias periféricas. Todavia, ele também apontou que os multiplicadores de gastos públicos não são inexpressivos, dependendo das condiçôes da economia, em especial, em situaçóes de grave capacidade ociosa, como a brasileira.

O trabalho de Orair, Siqueira e Gobetti (2016) calculou os impactos desses multiplicadores por diferentes classes de gasto e fases do ciclo econômico recente no país. Conforme tabela $\mathrm{I}$, em uma recessão, torna-se importante não só sustentar gastos em investimentos (ativos fixos), como a literatura usualmente afirmava, mas também os gastos com pessoal e benefícios sociais, o que se evidenciou em um efeito expressivo. Ao contrário, nessa fase, incentivos fiscais (subsídios) e demais despesas oferecem baixa resposta. Cabe observar que, no período recente, o governo fluminense buscou se "financiar" exatamente reduzindo esses repasses para fornecedores, beneficiários de programas sociais e servidores, e isso teve um forte componente recessivo. 
Tabela I - Efeito agregado dos multiplicadores fiscais segundo classes de despesas ${ }^{\mathrm{T}}$

\begin{tabular}{llllll} 
& Ativos fixos & $\begin{array}{l}\text { Benefícios } \\
\text { sociais }\end{array}$ & $\begin{array}{l}\text { Gasto de } \\
\text { pessoal }\end{array}$ & Subsídios & $\begin{array}{l}\text { Demais } \\
\text { despesas }\end{array}$ \\
\hline Linear & $\mathrm{I}, 04 \mathrm{I} 4$ & $0,84 \mathrm{I} 6$ & 0,6055 & $\mathrm{I}, 50 \mathrm{I} 3$ & 0,2476 \\
\hline Expansão & 0,1623 & 0,1536 & 0 & 4,7338 & $\mathrm{I}, 389$ \\
\hline Recessão & $\mathrm{I}, 6806$ & $\mathrm{I}, 5065$ & $\mathrm{I}, 3265$ & 0,5972 & 0,2637 \\
\hline
\end{tabular}

Fonte: Orair, Siqueira e Gobetti, 2016.

Para discutir o ajuste público dentro de uma perspectiva do que é mais importante para a recuperação econômica, é preciso esclarecer dois aspectos centrais. Primeiro, é mais improvável que o ajuste seja plenamente exitoso enquanto a economia estiver em recessáo (dado comportamento pró-cíclico da arrecadação já mencionado). Segundo, a decisão de cortes não deve ser naquelas áreas que amplifiquem a retração econômica, dado efeito multiplicador: investimento, benefícios sociais e, inclusive, despesa com pessoal (em particular, em situaçóes de demanda deprimida nas quais haveria pouca propensão a poupar). Cortes nessas áreas tendem a aumentar a recessão, ou seja, o problema do ajuste fiscal pode virar uma "bola de neve".

Nesse sentido, o suposto "remédio" corre risco de virar "veneno", ou seja, o ajuste pode contribuir não só para o quadro recessivo, mas também com o risco crescente do próprio Estado ser desestruturado à beira do caos social: agravamento do quadro de miséria e insegurança mais evidentes, desemprego em massa, maior mortalidade por piora nos serviços médicos e na assistência social, não cumprimento de metas educacionais etc.

Enfrentar isso exige que o ajuste fiscal seja tratado no contexto mais geral da importância estratégica da atuação do Estado, senão acabará por enfraquecê-lo em suas funçôes fundamentais. Cortes podem ser importantes em termos da eficácia do gasto, mas não para ser a principal saída de uma crise financeira. Por isso, é preciso cautela, um ajuste mais gradual e estrutural para fortalecer o papel do Estado em vez de cortes descoordenados na boca de um caixa vazio.

Ao se deparar com a necessidade de um ajuste fiscal, a distribuição do ônus deve se basear nos efeitos sobre o poder de compra do Estado e da populaçáo,

I. Para R \&,oo de aumento no gasto público. 
sendo fundamental um debate sobre o custo social de cada medida. Isso não se justifica apenas por um viés humanístico ou de justiça, mas também pode se tornar mais difícil o esforço de recuperação econômica. Especificamente, classes com maior propensão a gastar e o poder de compra do Estado não deveriam ser atingidos fortemente, pois garantem maior circulaçáo de renda em uma cadeia de atividades que dependem de sua demanda corrente.

\section{Aspectos-chave do acordo com o governo federal diante das diferentes visóes no debate sobre a problemática atual}

Um pacote de ajuste fiscal deve ser discutido seriamente, dentro do contexto da problemática específica regional que está inserido. Antes de um debate ideológico sobre reduzir o tamanho do Estado, o desafio é discutir uma forma de evitar a falta de financiamento para o seu papel estruturante sobre a economia. Em particular, isso se refere a uma discussão de natureza federativa, enquanto a coordenação de diversas instâncias de poder com autonomias relativas e uma diversidade de perfis socioeconômicos regionais. Portanto, refere-se a um problema de tomada de decisóes em uma situação que explicita problemas de coordenação política e fragilidade do sistema de encadeamentos.

Essa interpretação remete à discussão de Keynes (2002) no seu livro clássico Consequências econômicas da paz. Não seria exagero considerar que ele sustentou uma visão federativa de Europa nessa obra, logo, antes das discussões de formação de um bloco regional (o que só viria a ocorrer no pós Segunda Guerra Mundial). Isso porque permitiu compreender a importância de se estabelecer compromissos mútuos de cooperação inter-regional e desenvolvimento territorial integrado.

Náo se trata de um estudo teórico, e sim uma obra baseada em sua experiência política como membro da equipe britânica de negociação do Tratado de Versalhes (embora, indignado com o resultado, afastou-se das negociações antes que o texto fosse assinado). Diante do debate sobre a mensuração e distribuição das reparaçóes após a Primeira Guerra Mundial, o autor analisou o problema da dívida como instrumento de poder e dominação. É notória sua observaçáo sobre a opção por uma "paz cartaginesa", na qual se optou pelo enfraquecimento permanente do país derrotado, logo, as condiçôes atribuídas à Alemanha eram inviáveis economicamente. Isso não só sustentou o clima de tensóes políticas e as opçóes cada vez mais radicais de revanchismo diante 
de um quadro de humilhaçóes e drama social, bem como manteve a Europa como um todo incapaz de uma recuperação econômica definitiva.

Em especial, a obra demonstrou que a administração da dívida envolve questóes muito mais profundas que a mera preocupação com o reequilíbrio das contas públicas. A dívida pode se tornar impagável e servir para a imposição de cláusulas lesivas, enquanto estratégia de servidão financeira a partir da subordinação política e da expropriação econômica. Nesses termos, antes de um quadro de desequilíbrios contábeis, é preciso atenção ao de poder entre os envolvidos.

Por isso, Keynes alertou que existem dois critérios em discussão: a busca de disciplina fiscal máxima e mais voltada a priorizar os compromissos com o pagamento da dívida, ou evitar que a existência desta fosse um grave problema político que continuasse a ameaçar a estabilidade social e o reordenamento econômico de todos os envolvidos. A princípio, o primeiro critério pode ser mais vantajoso ao solidarizar perdas e impor a transferência de seus custos aos mais "desfinanciados" e com menor poder de barganha, porém, dinamicamente, uma carga exagerada de compensaçóes pode sustentar hostilidades e ter um efeito sistêmico indesejável, no qual se realimentam tensôes políticas e recessão econômica ampliada. Chamando atenção para o segundo critério, o objetivo fundamental é não dissociar os problemas estruturais ligados ao padrão de desenvolvimento e dos efeitos sobre o desempenho econômico agregado.

Inversamente, o acordo do governo do estado do Rio de Janeiro com o federal não leva em consideração essas relevantes consideraçôes. Opta por admitir uma "moral de tesouraria" com claro viés punitivo, para que o caso fluminense sirva de exemplo e laboratório para os demais entes subnacionais. Por isso, em vez de ênfase nas especificidades do caso estadual e de seu contexto histórico, explora generalidades que melhor servem para resumi-lo a um quadro de irresponsabilidade fiscal.

Todavia, a questão é bem mais complexa que o discurso oficial sustenta. $\mathrm{O}$ nó do problema é que as gestôes de estados e municípios estão impedidas legalmente de se autofinanciarem, ao contrário da federal. Logo, a União tem um poder não facultado aos demais entes da federação, algo decisivo em um momento de severa crise e conflito distributivo emergente. Diante disso, existem duas opçóes a seguir: I) a União assumir a coordenaçáo federativa e refazer um rearranjo desse pacto, o que demanda visão estratégica do interesse nacional e empenho de orçamento federal; ou 2) impor-se sançóes e contraparti- 
das severas às gestóes subnacionais prejudicadas em troca de maiores haveres e obrigaçóes renegociadas com endividamento crescente. Até o momento, a segunda opção é aquela que está avançando.

É importante esclarecer que não se trata do pleito de um estado, dado que deixa em aberto toda uma problemática a respeito da lógica assimétrica de tomada de decisão na federação. Cabe se indagar porque uns entes mantêm suas estruturas de gasto e outros se veem impedidos, ficando "desfinanciados" e vulneráveis à imposição de cláusulas lesivas. Torna-se evidente que o que os diferencia náo é simplesmente ter ou não responsabilidade fiscal, e sim poder segundo certo ordenamento federativo. Assiste-se a mais uma rodada de centralismo do ponto de vista tributário e financeiro que supera aquela que marcou a renegociação das dívidas dos entes subnacionais no final da década de 1990 e, até o momento, arrasta passivos consideráveis. Assis (2017) enfatizou como essa forma de administração das dívidas continua a ser um instrumento de poder e dominação em cerco de impossibilidades armadas por tramites político-jurídicos. Da mesma forma, nota recente do Conselho Federal de Economia (20I7) chama atenção para a essência federativa da atual crise financeira dos estados e municípios, cujo caso fluminense é o mais notório.

Portanto, a orientação contida no acordo federal oculta o desequilíbrio estrutural entre as funçóes atribuídas aos entes federativos e suas respectivas fontes de financiamento, e tende a realimentar tensóes políticas e recessão econômica ampliada graças a não articulação a qualquer plano de desenvolvimento nacional. Apenas se está flexibilizando algumas condiçôes da União como credora financeira, exigindo cortes de despesas mais severos e autorizando o governo estadual a antecipar receitas em troca de vender patrimônio e se endividar em uma situação fiscal mais arriscada. Sem alterar a estrutura de endividamento ou fortalecer as estaduais de planejamento econômico, revela-se o respaldo a um caso de "chantagem institucional", porque, caso contrário, a justiça autorizaria mais arrestos e bloqueios nas contas fluminenses sem questionar os graves efeitos socioeconômicos.

Quando se faz um diagnóstico, é fundamental separar a raiz do problema (vulnerabilidades latentes) dos fatores desencadeadores (agravamentos conjunturais). Os defensores do acordo federal apontam que a crise econômica nacional foi apenas um fator secundário que acelerou a evidência de um problema de gestáo estadual: uma "gastança" com folha de pagamento que leva a um cumulativo descompasso entre receitas e despesas. Desse modo, seu pon- 
to principal é a crítica ao que chamam de "rigidez orçamentária” em uma série de despesas obrigatórias que reduz os graus de liberdade para o ajuste fiscal.

Vescovi, antes de assumir o cargo da Secretaria do Tesouro Nacional e ficar responsável pela coordenação da equipe de técnicos sobre o acordo com o governo fluminense, já defendia que:

A tendência é novamente desconsiderar que os enormes prejuízos recaem na parcela mais vulnerável da população, que não pode barganhar cargos públicos nem benesses, não é protegida pela estabilidade no emprego, não pertence a nenhuma corporação e não é suportada por contribuiçóes compulsórias. Sempre os mais pobres pagam a conta do desequilíbrio fiscal com mais desemprego, ausência de educação de qualidade, hospitais deficientes e segurança precária (Vescovi e Costa, 2016).

É clara a visão tecnocrática sob tal orientação que transparece seu viés ideológico em uma entrevista recente que sentenciou que: "o reequilíbrio fiscal do Rio somente será obtido mediante uma redução do tamanho do Estado” (Vescovi, 2017, p. 16). Essa visão não contempla que uma economia capitalista moderna náo baseia sua capacidade de financiamento em atos de poupança, mas em um mecanismo de adiantamento de recursos. Desconsidera-se o caráter residual da poupança variável e aposta na possibilidade de a administração pública estadual economizar em um cenário de grave deterioração das receitas. Em termos práticos, ignora que esse ato subtrai da economia e reserva isso como uma riqueza não produtiva.

Inversamente, Barbosa (20I7) alertou que o ajuste do resultado primário deve ser distribuído no tempo para evitar que a política fiscal seja uma fonte de instabilidade macroeconômica. Em períodos de reduçáo do nível de atividade, o resultado primário deve absorver a maior parte da queda de receita para evitar cortes excessivos de despesa que afundem a economia ainda mais.

No geral, opositores ao acordo tendem a apontar que o problema náo está centralmente no lado da despesa, mas no das receitas. Uma interpretação corrente advoga que o problema de receita se dá principalmente por isençóes fiscais. Assim, curiosamente, adota-se uma dimensão estratégica semelhante à visão dos defensores do acordo: a raiz está na gestão estadual. A diferença é que seria por renúncia à receita e não por uma suposta "gastança" irresponsável. Dessa forma, também semelhante com a visão dos defensores do pacote, a cri- 
se econômica nacional é equivocadamente mencionada como um aspecto conjuntural apenas, logo, um fator secundário pouco enfatizado.

Caso se considere que esses são os dois polos opostos do debate, há então um "ponto cego" de convergência: a opção intencional por não nacionalizar a crise no estado do Rio de Janeiro, o que deixa transparecer os respectivos projetos de poder. Um projeto é ligado a uma "moral técnica" que eleva a Lei de Responsabilidade Fiscal a uma cláusula pétrea acima dos próprios valores constitucionais, de modo que será a Constituição brasileira que terá de se adaptar a suas determinaçóes. Nessa via, despolitiza-se uma série de questóes que poderiam estimular aspiraçóes sociais mais profundas, logo, incompatíveis com gestôes "blindadas" ao apelo popular (é notório a forma como recorrentemente se confunde democracia com demagogia ou populismo).

Outro projeto é ligado a uma "moral social" que parte de uma crítica ao sistema capitalista, mirando idealizar espaços de utopia, de modo que náo avança sobre formas efetivas de comandá-lo sob grandes blocos de capitais nacionais e complexos regionais integrados em um sistema territorial de produção. Dessa forma, esses oposicionistas visam tratar o problema descolado de sua essência econômica, enquanto interesse nacional e visão estratégica de longo prazo. Nessa linha, a isenção fiscal não é discutida como uma política econômica, e sim como mero "véu" de uma corrupção sistêmica. Assim, tratam o problema como combustível da própria disputa político-partidária no nível estadual, logo, não vocalizando e liderando um pleito pluripartidário a respeito da defesa de interesses regionais do Rio.

Contudo, o debate pode ir além dessas duas interpretaçôes. Isso porque o cerne da questão não se resume à disputa por qual moralidade escolher: a técnica ou a social. Isso porque a crise econômica nacional está longe de ser só um fator secundário. E se ela é algo central, entáo a no Rio tem que ser nacionalizada urgentemente para, a partir disso, enfrentar suas especificidades fundamentais.

Em vez de meros casos de "gastança" ou renúncia, a raiz do problema é mais complexa e está atrelada às características do padrão de desenvolvimento e à sua debilidade produtiva estadual. Sobral (2013 e 2017) caracterizou esta como um quadro de "estrutura produtiva oca", e, entre seus determinantes, impede que as receitas públicas tenham outro comportamento (inclusive, reduzir a dependência das rendas do petróleo e gás). Sendo assim, é essa debilidade que causa uma grave recessão com efeitos desproporcionais sobre a re- 
gião. Uma crítica mais adequada às isenções fiscais seria investigar até onde combateram o agravamento desse problema estrutural. Criticar isençóes sem focar na avaliação da desindustrialização não contempla a essência do debate que cerca a questão. Portanto, isençóes é um problema para ser tratado rigorosamente no debate sobre a qualidade da política industrial.

$\mathrm{O}$ equívoco mais retumbante para uma visão progressista seria achar que a melhor política industrial é não ter uma, ou, traduzindo para o caso específico, que a melhor política de incentivos fiscais é não tê-la. Uma significativa redução de isençóes exige superar a "guerra fiscal", um debate importantíssimo, mas que envolve uma reordenação do pacto federativo, logo, um tratamento nacional e nunca isoladamente na escala estadual. No mais, melhores encaminhamentos da questão na escala estadual se voltariam a uma discussão de como resgatar e atualizar uma estrutura permanente de planejamento integrado e planificação setorial.

Ao criticar a superestimação dada aos incentivos, não significa a ausência de problemas de gestão estadual. Ao contrário, o agravamento das condições se evidencia muito mais por uma exposição a um endividamento temerário e a forma pouco contundente que lida com disputas financeiras no cenário nacional: seja com a pouca recuperação da dívida ativa de empresas, seja com a não priorização de reparaçóes a exigir do governo federal (exemplo: Lei Kandir, defasagem no valor de royalties etc.). Soma-se a forma que mistificou o problema da previdência, isentando suas responsabilidades como mostrou relatório do TCE-RJ (20I7). Em particular, ocultam-se descapitalizaçôes realizadas, antecipaçóes desastradas de receitas e ausência de um plano de amortização que considerasse o custo de transição na fase atual de vigência de dois modelos organizacionais.

É preciso ter claro que o dinheiro de corrupção já apurado não "fecha a conta” do rombo total das finanças públicas. Por essa razão, apela-se à hipótese heroica de que a maior parte das isençóes também é corrupção . Contudo, as cifras alardeadas de incentivos estão sob forte controvérsia que variam em um intervalo enorme entre levantamentos do TCE-RJ e do governo estadual (para uma análise baseada no levantamento do TCE-RJ, ver artigo do Observatório de Benefícios - 20I6), grupos compostos por auditores fiscais da SEFAZ-RJ.

Segundo SEDEIS-RJ (20I6), a controvérsia se deu pelo uso da Base Autodeclarada de Incentivos Fiscais (BADIF) que não desconta o Montante Neutro de Incentivos Fiscais (MONIF), que equivaleria a 74\% do total. Em sua 
visão, isso não impacta as receitas públicas por serem valores compensados ao longo da cadeia produtiva ou por se tratarem de transferência de máquinas entre estabelecimentos da mesma empresa. Ademais, mesmo no restante, chamado de Valor Apurado de Incentivos Fiscais (VAPIF), 58\% são incentivos definidos por políticas do governo federal e concedidos nacionalmente pelo CONFAZ, logo, apenas II\% do BADIF seria fruto de atos do governo estadual. Mesmo que as maiores cifras estivessem corretas, o que é improvável pelas deduçóes não contabilizadas, um processo de recuperação desse dinheiro teria que ser mediado pelos seus impactos sobre as decisóes de investir e de produzir para não agravar a situação de uma economia regional já em frangalhos.

Desse modo, saídas da crise financeira atual dependem não só de maior mobilizaçáo reivindicatória, mas de diagnósticos com sentido mais prático para o enfrentamento do cerne do problema. É fundamental nacionalizar a crise no estado do Rio de Janeiro e cobrar as responsabilidades do governo federal. Afinal, a Uniāo possui meios para resolver os efeitos da crise nacional que ela infligiu aos estados e municípios com seus erros de política econômica, explicitando as debilidades estruturais destes últimos.

É falacioso o argumento de que o aporte de recursos do orçamento federal na economia fluminense deseja "quebrar" o Brasil, impedindo o ajuste fiscal federal (ou pior, ser inflacionista). Cabe assinalar que a União montou um novo Refis que permite perdoar dívidas empresariais de $\mathrm{R} \$ 543$ bilhóes, o que equivale a mais de 2,6 vezes o orçamento do estado do São Paulo, o mais rico da federação. Logo, o problema não é dominar aritmética nem ser irresponsável, mas que o governo federal compreenda a profundidade da crise no estado e descubra que recuperá-lo teria um efeito nacional muito maior que um lobby empresarial difuso sem nenhuma previsibilidade de consequência multiplicadora em termos de gasto e redinamização econômica.

Portanto, não se precisa de nenhuma solução fiscal irresponsável para socorrer o Rio de Janeiro, bastando um espírito republicano e coordenação federativa de um plano de recuperação nacional (o que sairia bem mais barato que um Refis). Sobre esse ponto, ganha pertinência comparar a situação do Rio de Janeiro com o que transcorre na peça $O$ mercador de Veneza, de Shakespeare (2005). Nessa peça, o usurário Shylock exige cobrar uma letra que permite cortar uma libra de carne do fiador da dívida. Para justificar o absurdo, agarra-se à lei que exige respeito aos contratos e ameaça que, se náo for respeitada a 
cobrança, todo o sistema legal e de negócios de Veneza estaria sob insegurança jurídica. Com a apelação da clemência e irresoluto, ele rebate que só exige a lei e que é seu de direito aquilo contido no texto. $\mathrm{O}$ revés ocorre quando o juiz chamado reconhece seu direito a um pedaço de carne pela dívida, porém, nada no trato firmado o autoriza a sangrar. Se não, estaria atentando contra a vida de um cidadáo e a mesma lei se viraria contra ele.

Shakespeare assim discute do que se trata a justiça que concebe um direito desde que este seja ponderado pelos riscos que impóe a outros direitos assegurados. E mais, que o direito à vida é superior a qualquer direito financeiro que o ponha em risco. Há uma frase central do juiz se referindo ao usurário: "reclamaste justiça; fica certo de que terás justiça, talvez mais do que desejaras" (Shakespeare, 2005, pp. 136-7).

Voltando à situação fluminense, as remuneraçôes dos servidores estaduais, de beneficiários de programas sociais não atendidos adequadamente e das empresas fornecedoras se tornaram fiadores da dívida estadual indiretamente. $\mathrm{O}$ governo federal age como a personagem Shylock ao cobrar sua dívida, pois a lei lhe autoriza, mesmo que isso signifique "cortar na carne" e pôr em risco condiçôes de manutenção dos fiadores envolvidos. Diante disso, o que se pode avaliar é o caso de, por vias políticas e jurídicas, fazer justiça mais do que o governo federal imagina.

Atualmente, a dívida estadual é de cerca de $\mathrm{R}$ \$ I07 bilhóes, sendo que $\mathrm{R} \$$ 73,6 bilhôes diretamente com a União. Os principais itens são associados aos acordos de renegociaçáo da dívida do final da década de I990, e repara-se que até hoje não foram quitados, embora o saldo atual (o que falta pagar e não tudo que já foi pago) signifique mais que o triplo do valor contratado. Em valores de janeiro, isso garante à União uma receita de $\mathrm{R}$ \$ I27,7 milhóes.

De fato, é permitido pela lei a cobrança por parte da União, porém, o mesmo governo estadual é credor de uma dívida ativa que se refere a impostos não pagos de diversas empresas. Reunindo-se o que é devido, essa dívida ativa empresarial está em torno de $\mathrm{R} \$ 69$ bilhões, valor muito próximo à dívida do estado do Rio com a União (lembrando, $\mathrm{R} \$$ 73,6 bilhões). Boa parte dela é considerada impagável, sendo que a taxa de recuperação é bem baixa, pois depende do sistema jurídico, o mesmo que garante o direito da Uniáo.

Segundo dados da Procuradoria Geral do Estado do Rio de Janeiro, as duas empresas com maior volume de dívida ativa são estatais federais: Petrobrás $\left(\mathrm{R}_{\$}\right.$ 4,4 bilhóes) e Correios ( $\mathrm{R}$ I,6 bilhóes). Sendo o governo federal acionista ma- 
joritário delas, poderia ser questionado. Outro detalhe é que a dívida ativa de empresas do ramo de petróleo e gás está em torno de $\mathrm{R} \$ 8$ bilhóes (incluindo Petrobrás). Contudo, é o mesmo setor que pressiona a ANP para retardar a atualização da tabela dos valores a serem pagos de royalties e participaçôes especiais ao governo do Rio. Isso gera anualmente uma perda estimada de $\mathrm{R} \$ 2$ bilhôes, fora valores retroativos a serem exigidos. Não há controvérsia, bastaria que se cumprisse a lei.

Existem outros pontos a serem discutidos, como reparaçóes pela Lei Kandir, bem como retomar o debate sobre a não cobrança das perdas pelo ICMS do petróleo na origem. Toda a questão ignorada pelo governo federal, que anseia por cobrar sua dívida, e o estadual se respalda no discurso de que o servidor estadual e a sociedade em geral precisam fazer "sacrifícios".

É inegável que a justiça precisa cumprir a lei. Portanto, cabe discutir os valores que são fundamentais e refletem sabedoria política na sua defesa, ampliando o horizonte do possível. Para uma visão similar à da personagem Shylock, basta a retórica de uma "moral de tesouraria" a respeitar os compromissos de dívida. Contudo, cabe indagar qual direito é soberano diante de uma tensão federativa explícita entre entes governamentais e um conflito distributivo que pesa em favor de certos grupos de interesses de forma acrítica.

\section{Bases para um diagnóstico crítico à visão contida no acordo federal a partir da ênfase nas especificidades fluminenses}

A ênfase da crítica ao acordo deveria estar em um problema de debilidade produtiva que foi explicitado por um cenário de enorme tensão federativa, o que agravou os efeitos da exposiçáo governamental a um endividamento temerário. Qualquer outra condução, mesmo que se oponha ao acordo federal, não oferecerá condiçôes objetivas de reorientá-lo sem antes modificar a dimensão estratégica do diagnóstico que não foca em nacionalizar a questão fluminense, mantendo seu governo estadual e sua economia como problemas isolados.

Primeiramente, é preciso ter claro que o cerne da crise financeira do governo do estado do Rio de Janeiro se deve mais pela queda de receitas do que pelo aumento das despesas, as quais também estão em redução. $\mathrm{O}$ problema é que aquelas estáo caindo em um ritmo mais acelerado do que estas, como mostra o gráfico I. É preciso ter consciência de que um ciclo vicioso se estabeleceu, no qual se faz progressivamente maiores cortes de despesas (e ainda se recomen- 
da mais), e as receitas apresentam uma queda ainda maior. O gráfico 2 mostra a gravidade do quadro para o ano de 20ı6, quando a retração da arrecadação própria fluminense foi a maior entre os estados brasileiros.

Não se priorizando uma inflexão na deterioração das receitas, o desajuste fiscal persiste, tornando inócua a aposta reiterada em maiores endividamentos e redução da máquina pública, em particular, no contexto atual de recessão e carências sociais. Em particular, porque não se trata apenas de uma forte queda das receitas, mas isso em um contexto de capacidade de geração de receita própria estruturalmente baixa.

Como mostra o gráfico 3, o caso fluminense é aquele com a menor taxa média anual de crescimento da receita corrente líquida, considerando-se também as três gestóes anteriores. Logo, não se trata apenas de um problema conjuntural e sim estrutural, explicitado em uma situaçáo de maior vulnerabilidade (forte queda das receitas do petróleo e gás natural e recessão econômica nacional). E mais, o desempenho fluminense é bem diferente dos casos mineiro e gaúcho dos quais, muitas vezes, alguns analistas tratam imprudentemente de forma conjunta.

Gráfico I - Evolução de receitas e despesas primárias do governo fluminense em termos reais entre 2003 e $2016^{2}$

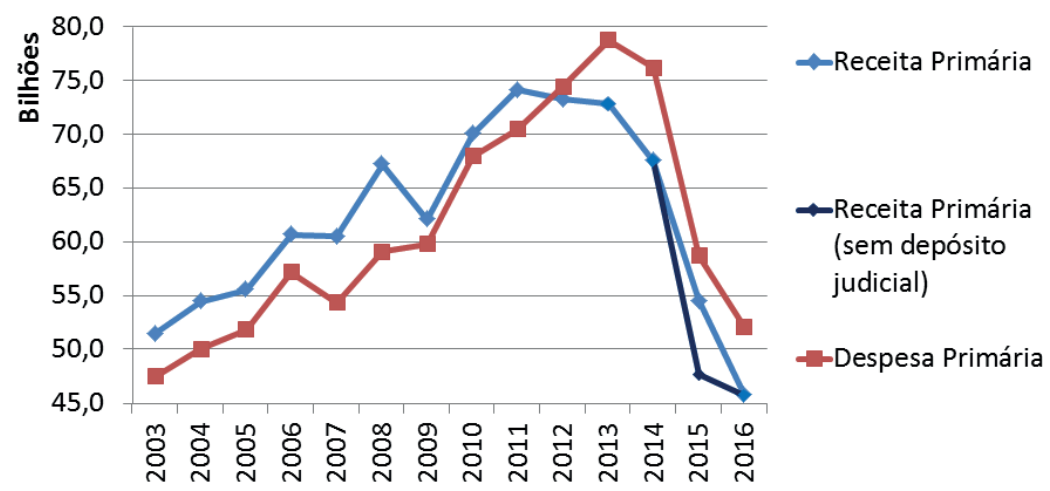

Fonte: SEFAZ-RJ.

2. Valores corrigidos pelo IPCA (dez./2016). 
Gráfico 2 - Variação real (\%) das receitas primárias dos estados entre 2015 e 2016

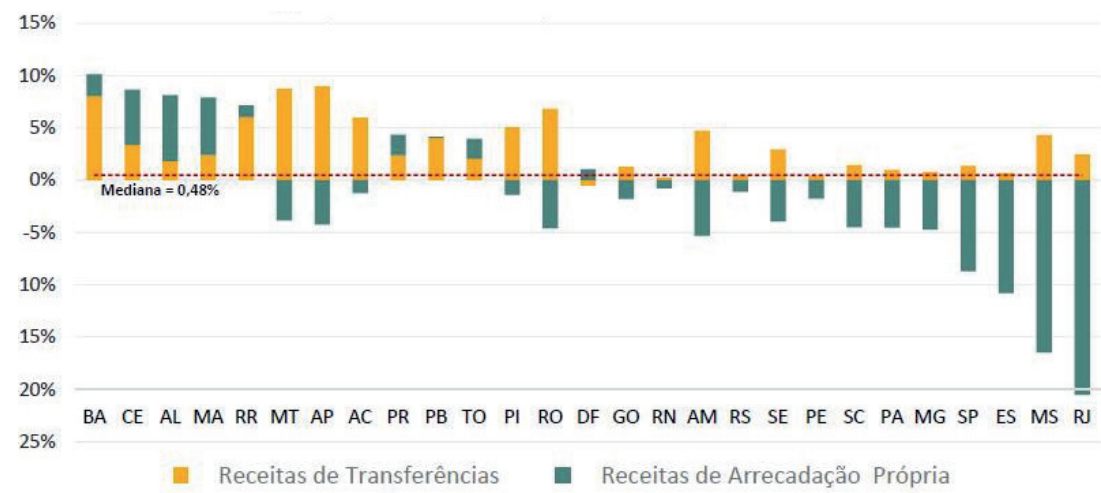

Fonte: Sistema do Tesouro Nacional.

Gráfico 3 - Taxa média anual de crescimento da RCL entre 2002 e $2016^{3}$

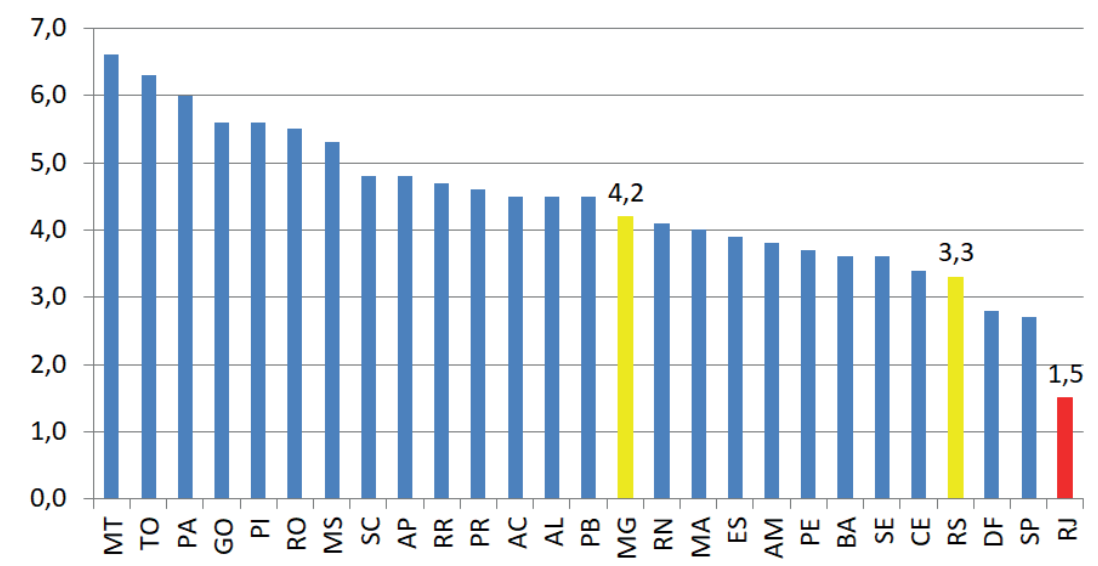

Fonte: STN e secretarias estaduais.

Como mostra o gráfico 4, já há uma exposição temerária a um endividamento acelerado, o que foi induzido pelo governo federal em três fases. No início, isso se justificava para a realização de investimentos de interesse nacional não realizados diretamente pelo governo federal, apoiando o endividamento dos governos estaduais em seu lugar. É inegável a importância dos investi-

3. Valores corrigidos pelo IPCA (dez/2016). 
mentos públicos realizados. Todavia, ao escolher facilitar o crédito em bancos públicos federais, a União não impactou suas contas, embora esses investimentos fossem de interesse nacional (em sua maioria, voltados para grandes eventos) e pudessem ter sido feitos com uso de orçamento federal. Precisando ser feitos "a toque de caixa" e em um volume considerável, mostraram-se incompatíveis à capacidade de suporte de uma administração estadual.

Em uma segunda fase, houve a tentativa de sustar temporariamente os efeitos de uma recessão nacional que se julgava passageira no discurso oficial federal. Porém, ao se alongar, transformou esse processo em uma "bola de neve". Assim, anteciparam-se receitas, ficando descoberto o fluxo de caixa no futuro próximo. Desse modo, não só houve um desempenho pior de geração de receitas, como também um ganho de um passivo ao invés de uma receita garantida. Sem ter recomposto receitas para cumprir os compromissos, necessita-se de mais recursos sem condiçóes de solvência para contrair mais créditos.

No momento atual, transcorre a terceira fase, em que a gestão federal tenta fazer seu ajuste das contas diretamente à custa dos entes subnacionais como o estado do Rio de Janeiro. Ao impedir que financie seu déficit por meio do orçamento, como o mesmo fez, empurra a gestão fiscal estadual para um comportamento cada vez mais especulativo: endividamento crescente, em uma lógica de dívida sobre outra.

Gráfico 4 - Evolução da DCL em \% da RCL de estados selecionados entre 2006 e $2016^{4}$

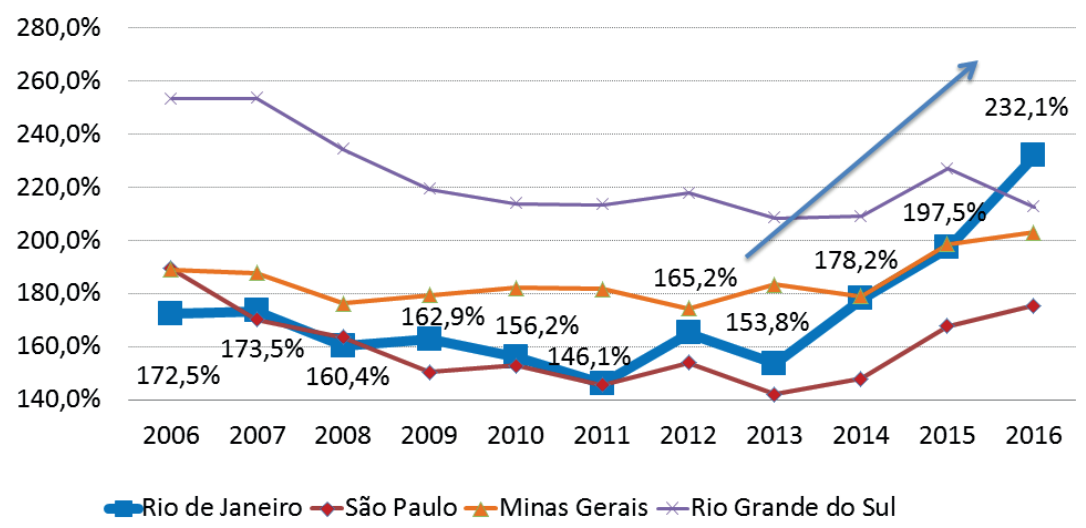

Fonte: Tesouro Nacional e secretarias estaduais.

4. Posição em 3I/oI/20I7. 
Como o gráfico anterior mostrou, mais uma vez é bem diferente a trajetória fluminense dos casos mineiro e gaúcho. Especificamente, entre 2012 a 2015, foram contratados $\mathrm{R} \$ 22,39$ bilhóes em empréstimos. Cabe ainda destacar as obrigaçóes no valor de $\mathrm{R}$ I 8 , 4 bilhôes até 202I pela antecipação de $\mathrm{R} \$ 8,4$ bilhóes em royalties e participaçóes especiais no período recente. Consequentemente, já há um alto patamar de desembolsos obrigatórios para os próximos dez anos (no total, em torno de $\mathrm{R} \$ 82$ bilhôes).

Insistir em mais endividamento, tendo a retórica do "dever de casa" sobre contrapartidas como algo indiscutível, é desconsiderar que, daqui para frente, economias substanciais só serão possíveis com o sucateamento ou corte de serviços públicos e com o descuido na preservação de fatores portadores de futuro (vide a agonia da UERJ, entre tantos outros exemplos). Como aponta o gráfico 5, a evolução das Despesas Primárias em percentual da Receita Corrente Líquida - RCL revela um violento tranco nos dispêndios feito ano a ano. 2016 chegou ao menor patamar atingido por esse indicador, desde o início da década de 2000, mesmo com a RCL sofrendo uma queda considerável nos últimos anos.

Gráfico 5 - Evolução das Despesas Primárias em percentual da Receita Corrente Líquida entre 2003 e $2016^{5}$

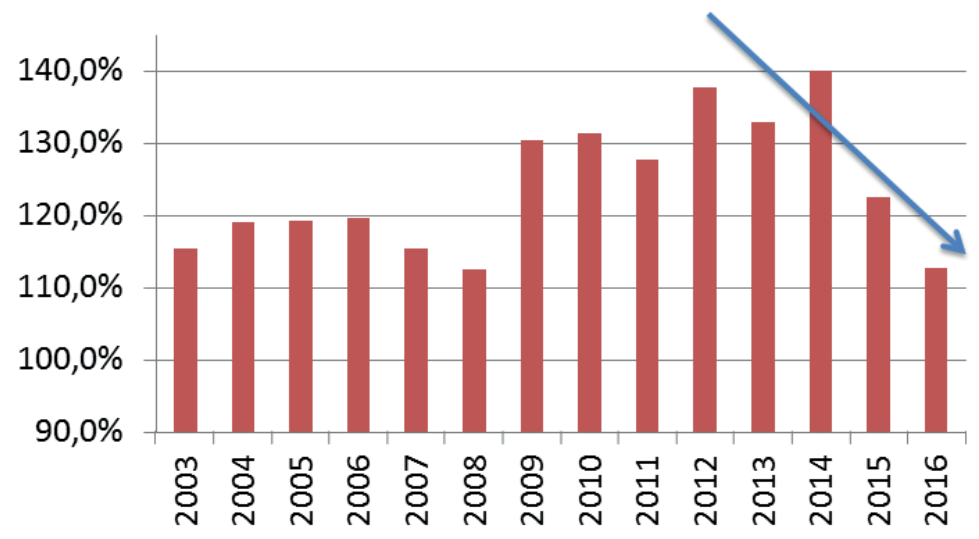

Fonte: Contas de Gestão / SEFAZ/RJ.

5. Dados de 2015 não consideram depósitos judiciais. 
Todo o debate que foca exclusivamente nas finanças públicas acaba enfatizando a folha de pagamentos sem contextualizá-lo como o efeito de um problema maior e com outras especificidades. É fundamental que todo o debate de finanças públicas não desconsidere a dimensão da economia regional e seus desafios que tornam necessária a recuperação e sustentação de instituiçóes estatais com visão de futuro.

A situação do Rio de Janeiro tem especificidades, principalmente a problemática de sua "estrutura produtiva oca". Como exemplo, o gráfico 6 apresenta a evoluçáo do crescimento do valor bruto total adicionado do estado do Rio de Janeiro e da média nacional no período entre 2002 e 20I4. Nota-se que, no acumulado, o estado do Rio de Janeiro possui desempenho pior e somente em dois anos se aproximou da média nacional: 2009 e 20I4. Justamente nos anos cuja trajetória do VAB total para o Brasil piorou, ou seja, a aproximaçáo se deu devido à piora da economia brasileira, e não porque a fluminense foi melhor. Quando a economia nacional vai bem, a fluminense náo acompanha na mesma intensidade.

Diante disso, explicitou-se um desempenho tributário estruturalmente aquém do porte de sua economia regional. Segundo a tabela 2, em uma comparaçấo entre estados do Rio de Janeiro e São Paulo, o PIB é quase três vezes menor e a receita tributária líquida é quase cinco vezes menor. Essa desproporçấo significa uma receita tributária líquida $56,6 \%$ menor, ou seja, perdas anuais em torno de $\mathrm{R} \$ 22,3$ bilhóes. Se isso fosse superado, cobriria o déficit orçamentário previsto na LOA para 2017 ( $\mathrm{R}$ 20,3 bilhōes).

Gráfico 6 - Série encadeada do crescimento do volume do valor adicionado bruto (VAB) total entre 2002 e 2014

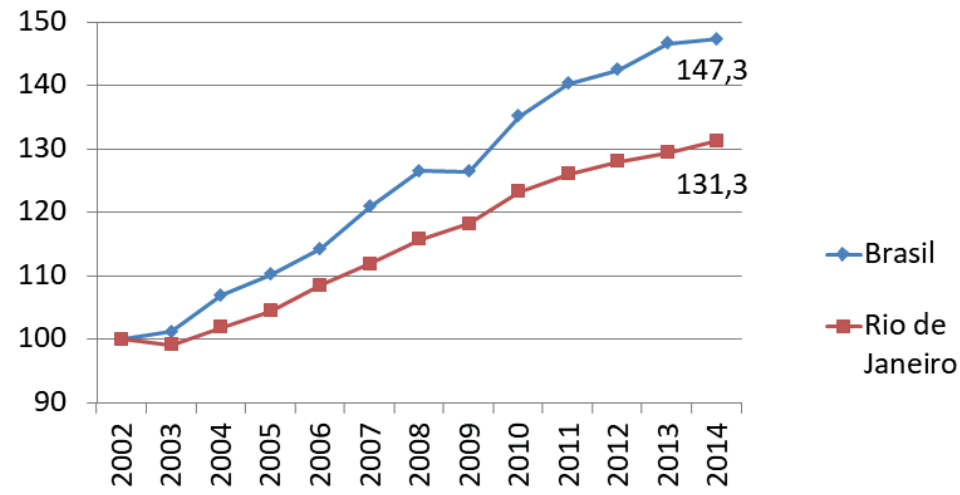

Fonte: Contas Regionais/IBGE. 
Tabela 2 - Comparativo PIB e Receita Tributária entre os estados de Rio de Janeiro e São Paulo

\begin{tabular}{|c|c|c|c|c|}
\hline \multirow[t]{2}{*}{ Estados } & \multicolumn{2}{|l|}{ PIB } & \multicolumn{2}{|c|}{ Receita Tributária Líquida } \\
\hline & Valor (em R\$ bilhóes) & $\%$ & Valor (em R\$ bilhóes) & $\%$ \\
\hline \multicolumn{5}{|l|}{ Dados reais: } \\
\hline Rio de Janeiro & $671, I$ & $36, \mathrm{I} \%$ & $29, \mathrm{I}$ & $20,5 \%$ \\
\hline São Paulo & I. 858,2 & IOO,०\% & $\mathrm{I} 42,2$ & $\mathrm{IOO}, \mathrm{O} \%$ \\
\hline \multicolumn{5}{|c|}{ Simulação de proporcionalidade: } \\
\hline Rio de Janeiro & $67 \mathrm{I}, \mathrm{I}$ & $36, \mathrm{I} \%$ & $5 \mathrm{I}, 3$ & $36, \mathrm{I} \%$ \\
\hline São Paulo & I. 858,2 & $100,0 \%$ & $\mathrm{I} 42,2$ & $\mathrm{IOO}, \mathrm{O} \%$ \\
\hline \multicolumn{3}{|c|}{ Diferença pela desproporçáo: } & $-22,3$ & $56,6 \%$ \\
\hline
\end{tabular}

Fonte: SICONFI/STN/MF e IBGE, dados retrabalhados a partir de Osório (2016).

Diante desse quadro, evidencia-se que as despesas com pessoal não explicam a situaçáo caótica em que se encontram as finanças públicas fluminenses. Segundo o gráfico 7, em 2015, mais uma vez diferente de Minas Gerais e do Rio Grande do Sul, o peso das despesas com pessoal no total de despesas primárias ainda foi um resultado mediano se comparado com os outros. Deve-se ponderar que há uma tentativa de maiores cortes em todas as despesas não obrigatórias, logo, as primárias tendem a se concentrar nessas (como as com pessoal), o que aumentará provavelmente o valor desse indicador nos próximos exercícios.

Gráfico 7 - Peso (\%) das despesas com pessoal no total de despesas primárias em $2015^{7}$

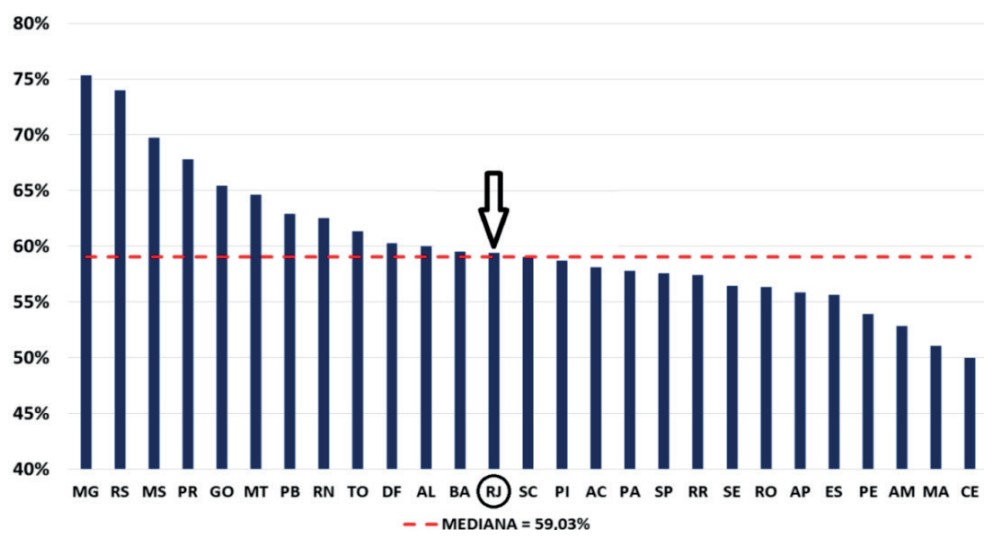

Fonte: STN.

6. PIB para exercício de 2014 e receitas tributárias para exercício de 2015.

7. Em 2016 , foi $64,2 \%$ para o Rio de Janeiro. 
Ao contrário do que presume uma visáo generalista de um Estado perdulário contida no acordo federal, o caso fluminense não é de uma máquina pública "inchada" (em particular, no poder executivo). Logo, focar na redução de seu tamanho tende mais a gerar perdas de eficiência em termos de papel econômico estruturante e capacidade de atendimento das demandas sociais. Como se nota nos gráficos 8 e 9 , proporcional ao PIB da renda domiciliar e da receita (pública) corrente líquida, a despesa com pessoal ativo do poder executivo fluminense é uma das menores (quando não a menor) em comparação com os demais estados.

Esse ponto é decisivo: em vez de menos, a administração pública está com composição de diversas áreas bastante envelhecidas e carentes de concursos, uma vez que ainda se encontra bastante desestruturada. A ocupação de funçôes permanentes por cargos comissionados, prática excessiva de terceirizaçôes, diversas áreas carentes de pessoal (em particular, prestadores de serviços essenciais) etc. denotam a falta de concurso, um problema estrutural que não só afeta a qualidade do serviço público, como inclusive reduz a base de financiamento previdenciário. Ou seja, prejudica o ajuste em seu aspecto mais enfatizado na opinião pública.

Gráfico 8 - Despesa com pessoal ativo no poder executivo fluminense em \% do PIB e da Renda Domiciliar em 2015

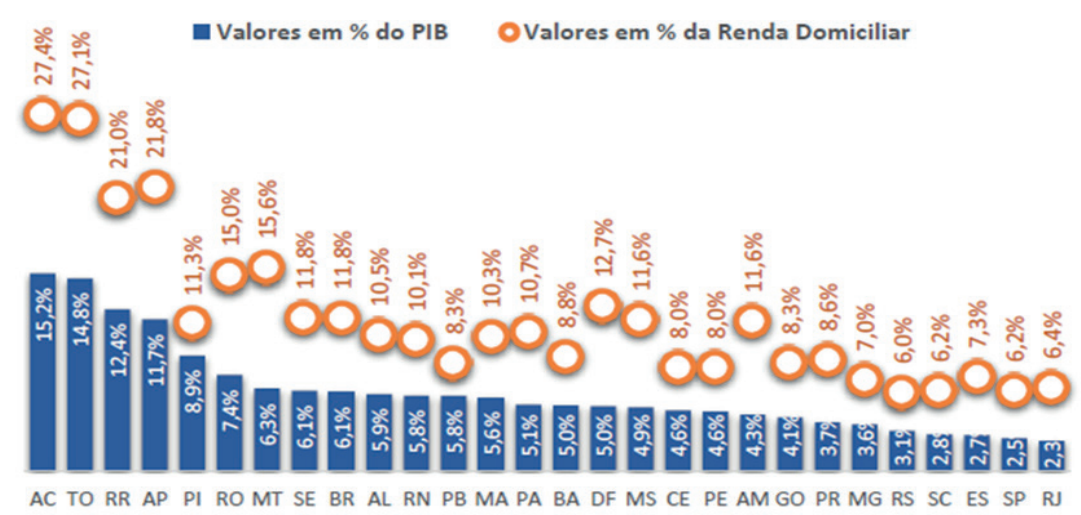

Fonte: Afonso, 2016. 
Gráfico 9 - Despesa com pessoal ativo no poder executivo fluminense em \% da Receita Corrente Líquida em 2015

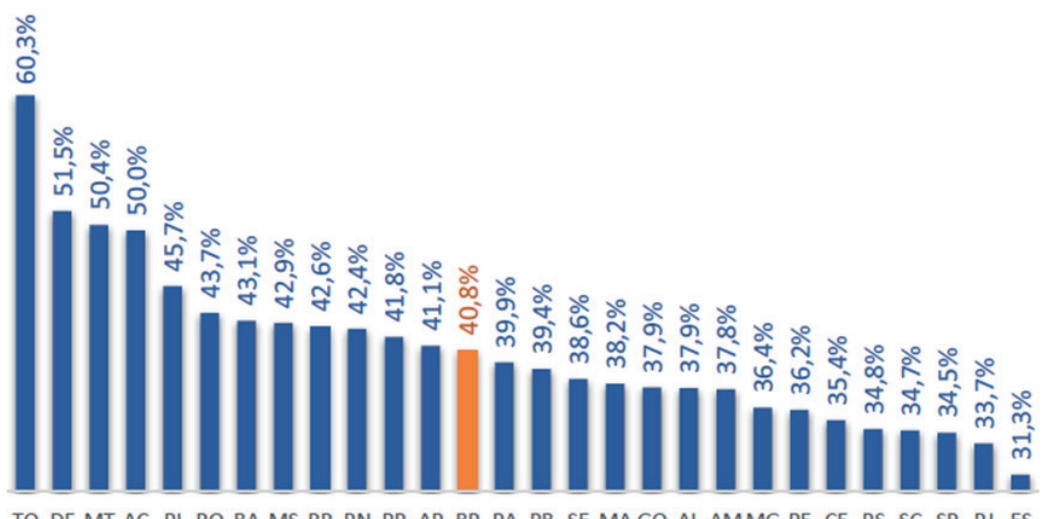

Fonte: Afonso, 2016.

Ao longo dos últimos anos, os servidores e a população atendida pelos serviços estaduais já sentiram uma tentativa indiscriminada de austeridade fiscal: interrupção de políticas públicas e precarização (se não sucateamento explícito) de instituiçôes de excelência e prioritárias para as massas populares. Diante de um Estado desestruturado, não se pode oferecer veneno como remédio, caso contrário, seria fazer laboratório de teses com o sofrimento alheio.

Ao explorar generalidades que melhor sirvam para resumir a um ideal de redução do tamanho do Estado, é necessário se responsabilizar em informar as áreas que sofrerão cortes profundos, em particular, sem afetar as políticas públicas. $\mathrm{O}$ acordo náo é o fim de um processo de tensôes federativas, mas o começo de um duro alinhamento que tende a se explicitar como estratégia de servidão financeira a partir da subordinação política e da expropriação econômica.

Afinal, graças ao acordo, respaldou-se um conjunto de argumentos bem apriorísticos e sem um debate mais responsável. Como exemplo, em entrevista recente, Barbosa (2017), secretário de fazenda fluminense, aposta que a venda de empresas públicas melhora os serviços para a população atendida sem ter se baseado em qualquer modelo de regulaçáo -, bem como aposta que o impedimento do governo do estado do Rio de Janeiro em contrair crédito para fazer novos investimentos abrirá oportunidade para investidores privados. Portanto, sua visão está na contramão das evidências mais recentes sobre 
as dificuldades enfrentadas por concessionárias de serviços públicos em diversos países, inclusive, sucedendo-se experiências de reestatizaçáo, o que permite reavaliaçôes como aquelas apresentadas no estudo de Kishimoto e Petijean (2017). Além disso, o respectivo secretário claramente dá pouca importância ao efeito multiplicador do gasto público e seu potencial de redinamização econômica, inclusive, seu impacto sobre a arrecadação pública.

Por outro lado, o acordo cria dissenso e desmobilização temporários entre os grupos de interesse afetados, e esse déficit de atenção favorece a imposição futura de atos ainda mais lesivos como algo inadiável pela gravidade dos fatos. Como exemplo do risco que se corre, um parecer recente da Secretaria do Tesouro Nacional (2017) já contém a sugestão de uma revisão da oferta de ensino superior, proposta de intervenção em uma política pública estadual em nenhum momento colocada antes em discussão até a assinatura do acordo.

Por isso, é importante que não se confunda alívio com solução. É fundamental se antecipar ao projeto de consenso forçado em vias de se consolidar. Em especial, cabem alguns alertas. Primeiro, o cenário federativo é marcado por uma série de controvérsias sobre o que entes subnacionais e o governo federal devem reciprocamente. Porém, assinando o acordo, fica-se impedido de qualquer questionamento judicial. Segundo, cria-se um conselho de supervisão que retira autonomia de um governo estadual eleito, pois terá acesso direto, por meio de senhas e demais instrumentos de acesso, aos sistemas de execução e controle fiscal.

Terceiro, a finalidade do acordo é apenas estabilizar a dívida líquida. Trata uma economia em recessão e com problemas estruturais como se tivesse um fluxo fiscal sustentado e com alguma previsibilidade, mesmo sem nenhuma ação indutora do gasto público. Quarto, se ocorrer divergência entre os valores realizados e os estimados na modelagem, exigem-se medidas compensatórias. $\mathrm{Na}$ prática, isso significa que, não batendo metas, há risco às políticas públicas, dado que se terá um teto de gasto e limite de acesso ao sistema para subordinar qualquer outra prioridade à questão da dívida.

Por último, apesar de ser tratado como um aperfeiçoamento da Lei de Responsabilidade Fiscal, esta previa que não se poderia deixar sequer restos a pagar para uma administração seguinte. Contudo, será admitido um passivo e uma série de encargos muito mais graves. Ao contratualizar pontos centrais de um programa de governo, criam-se riscos à possibilidade de alternância de poder, algo caro à democracia. 
Diante disso, é preciso ter em mente que o acordo não é um "socorro", dado que não há empenho de recursos do orçamento federal nem preocupação central com a grave situação socioeconômica estadual. $\mathrm{O}$ acordo favorece, a princípio, maior endividamento e parte de uma narrativa que náo contempla as especificidades do problema estadual: uma máquina pública "não inchada” (mas desequilibrada entre os poderes e com o executivo desestruturado), e um período anterior que, em vez de bonança econômica, explicitou uma "estrutura produtiva oca”.

Esse último conceito merece ser trazido ao centro do debate que envolve não apenas uma gestão desorganizada para lidar com a forte queda das receitas, mas um patamar de geração de receitas estruturalmente baixo. Isso foi agravado pela pouca ênfase dada a uma série de questóes tributárias e federativas (ICMS do petróleo, atualização dos royalties, Lei Kandir, dívida ativa etc.). Tais desafios ainda permanecem diante de um governo federal que se comporta semelhante a um "agiota". Isso exige que os alertas não sejam desconsiderados para alguma margem de negociação futura e para que uma frente política capaz de melhor defender os interesses do Rio ganhe força.

\section{Conclusão}

O principal desafio da atualidade no Brasil é superar a negação da política. Não precisa muito tempo em qualquer discussão para se colher opinióes raivosas sobre a classe política, acusando-a de todos os males atuais. $\mathrm{O}$ resultado prático é a generalização de uma crença na possibilidade de decisôes públicas apenas guiadas pela "boa" técnica. Como lógica idealizada, acredita-se retoricamente que dessa forma náo estaria sujeita a posiçóes controversas, pois ela seria "racional" e sem "paixôes" políticas. Isso faz com que a indignação acerca dos políticos dê salvo conduto para tecnocratas assumirem o comando do processo histórico nacional.

Nesses termos, o papel dos políticos se apequenou, e eles muitas vezes cumprem ordens dos tecnocratas, náo mais o contrário, como em qualquer democracia plena. Dizer que se luta contra a negação da política é reconhecer a necessidade de inversão dessa correlaçáo de forças, ou seja, fazer com que os tecnocratas se submetam a uma decisão política que não criem impasses à apresentação de um maior leque de alternativas. Bobbio (1997) alertou que a tecnocracia é a antítese da democracia. 
Mesmo a via da judicialização não é um substituto perfeito à via da politização. Não existe sistema de governo comandado pelo poder judiciário. Este vem se revelado bom para proferir muitos discursos sobre a moralidade, mas deixa de se posicionar diante de um conflito distributivo duríssimo. Assim, resume-se um grande quadro de tensóes a uma questáo de racionalidade absoluta, ocultando o juízo de valor que se faz ao desconsiderar as assimetrias entre os grupos de interesse e reduzir o horizonte de possibilidades de soluçáo a opções "neutras" só aparentemente.

Não há alternativa à política, única via realmente democrática e representativa para mediação de conflitos. $\mathrm{O}$ resto é credo em uma nova aristocracia ilustrada, mas que não tem o mandato do único soberano, o povo. Diante disso, é válido questionar até que ponto a forma como se tem tratado a crise das finanças do governo fluminense não fere o princípio republicano e o da dignidade humana.

O princípio republicano sugere que as administraçóes governamentais se guiem pelo interesse público em consonância à soma de outros: legalidade, igualdade, responsabilidade, impessoalidade, moralidade, razoabilidade etc. Tal fato significa que um gestor público só está autorizado a fazer aquilo que a lei, antecipadamente, determina. Da mesma forma, não devem ser cabíveis favoritismos, perseguiçóes ou desmandos que se desdobrem em atos lesivos ao patrimônio público. Ademais, cabe ser respeitada a isonomia dos administrados, não conferindo privilégios ou discriminaçóes de qualquer espécie.

Nesse sentido, a razão pública não deve se guiar pela subjetividade, uma vez que ninguém desempenha funçôes políticas por direito próprio. Agir de forma contrária seria negar a predominância do sentido da função institucional sob as razóes pessoais e a observância ao conjunto de direitos fundamentais, como o princípio da dignidade humana. Esse último, por exemplo, não se dissocia da proteção absoluta e irrestrita dos salários e provimento dos trabalhadores por garantias constitucionais.

Portanto, náo se trata de desconsiderar a margem de discricionariedade administrativa na execução do orçamento, mas de alertar para a produção de arbitrariedades cumulativas que tornam a lei orçamentária quase uma ficção, colocando em risco o patrimônio público e desamparando muitas pessoas com relação ao essencial para a subsistência (ou seja, direito à vida). Na retórica do acordo federal, isso tudo é temporário, devido a uma conjuntura ruim. Porém, análises mais atentas ao sentido das reformas associadas denotam que isso é um legado. 
Em disputa política, há um "novo normal” face um alinhamento dessa gestão com a visão política e os grandes interesses por trás do governo da União. Quem luta contra as reformas federais socialmente controversas deve tomar consciência disso e se mobilizar também contra uma reforma federativa disfarçada e imposta, fruto da chantagem institucional e da permissividade com seu poder de agiotagem sobre a dívida estadual. Portanto, precisa-se enxergar que a questáo vai muito além de um problema de gestáo particular. Caso contrário, outros governos estaduais e municipais politicamente fracos assinarão também suas "renúncias" a qualquer programa de desenvolvimento e políticas públicas, conforme o fluminense.

A solução é federativa e, para isso, é preciso nacionalizar com urgência a crise no estado do Rio de Janeiro, o que exige uma articulação para politizar contra mais essa reforma. No mais, é fundamental uma frente ampla da sociedade organizada para que este mostre qual lugar que lhe cabe na federação brasileira.

\section{Referências}

AFONSO, J. R. e PINTO, V. "Despesa pessoal com pessoal ativo e do executivo: uma comparaçấo entre unidades federativas”. Caderno virtual do IDP, v. 2, n. 35, 2016.

ALESINA, A. e PEROTTI, R. "Fiscal expansions and adjustments in OECD countries". Economic Policy, n. 2I, out. 1995 .

ASSIS, J. C. Acerto de contas: a dívida nula dos estados. Rio de Janeiro: MECS Editora, 2017.

ÁUREO, C. "Podemos ter saldo positivo em 2020", diz secretário do estado do Rio de Janeiro (Entrevista). Revista Época. Disponível em: epoca.globo.com/economia/noticia/20I7/o6/ podemos-ter-saldo-positivo-em-202o-diz-secretario-do-estado-do-rio-de-janeiro.html. Acesso em: I2 jul. 2017.

BARBOSA, G. "O plano para salvar o Rio é à prova de demagogia", diz secretário de Fazenda (Entrevista). Revista Época. Disponível em: epoca.globo.com/economia/noticia/2017/og/o-plano-para-salvar-o-rio-e-prova-de-demagogia-diz-secretario-de-fazenda. html. Acesso em: II set. 2017.

BARBOSA, N. "O retorno da austeridade fiscal expansionista". Jornal GGN. Disponível em: jornalggn.com.br/noticia/o-retorno-da-austeridade-fiscal-expansionista-por-nelson-barbosa. Acesso em: 5 abril 2017.

BLANCHARD, O. et al. Rethinking macroeconomic policy, IMF Staff Position Note, feb. 2010. e LEIGH, D. Growth forecast errors and fiscal multipliers. Washington: International Monetary Fund, 20I3 (IMF Working Paper, WP/I3/I). 
BOBBIO, N. O futuro da democracia: uma defesa das regras do jogo. Rio de janeiro: Paz e Terra, I997. CONSELHO FEDERAL DE ECONOMIA. "A crise financeira dos estados e municípios". Disponível em: http://www.corecon-rj.org.br/anexos/EBID33AA3526EoBIAC507C5CD7oB4CAo.pdf. Acesso em: 04 set. 2017.

DE LONG, J. B. e SUMMERS, L. H. "Fiscal policy in a depressed economy". Brookings Papers on Economic Activity, Spring, 2012.

GIAVAZZI, F. e PAGANO, M. "Can severe fiscal contractions be expansionary? Tales of two small european countries". NBER Chapters in NBER Macroeconomics Annual, v. 5, pp. $75-$ I22, 1990.

HALL, R. E. "By how much does GDP rise if the government buys more output?" National Bureau of Economic Research, n. I5496, Working Paper, 2009.

HIRSCHMAN, A. Estratégia de desenvolvimento econômico. Rio de Janeiro: Fundo de Cultura, I96I.

ISLAM, I. e CHOWDHURY, A. "Revisiting the evidence on expansionary fiscal austerity: Alesina's hour?”. Vox Policy Portal, 20I2. Disponível em: voxeu.org/debates/commentaries/ revisiting-evidence-expansionary-fiscal-austerity-alesina-s-hou. Acesso em: I7 jul. 2017.

KEYNES, J. M. Consequências econômicas da paz. Brasília: Editora da UNB, 2002.

KISHIMOTO, S. e PETIJEAN, O (ed.). Reclaiming Public Services: how cities and citizens are turning back privatization. Amsterdam e Paris: Transnational Institute, jun. 2017.

MOUNTFORD, A. e UHLIG, H. "What are the effects of fiscal policy shocks?". Journal of Applied Econometrics, v. 24, n. 6, pp. 960-92, 2009.

MYRDAL, G. Teoria econômica e regióes subdesenvolvidas. Rio de Janeiro: Saga, 1957.

OBSERVATÓRIO DOS BENEFÍCIOS. “Jogando luz na escuridão”. Disponível em: www. sidneyrezende.com/jogando-luz_.pdf. Acesso em: II set. 2016.

ORAIR, R. et al. "Política fiscal e ciclo econômico: uma análise baseada em multiplicadores do gasto público”. XXI Prêmio Tesouro Nacional 20I6. Disponível em: www.tesouro.fazenda.gov.br/documents/IoI80/558095/20-lugar-rodrigo-octavio-orair-o86.pdf. Acesso em: I5 nov. 2016.

PEROTTI, R. "Estimating the effects of fiscal policy in OECD countries". European University Institute and Center Economic Policy Research Draft, 2002.

PIRES, M. Politica fiscal e ciclos econômicos: teoria e a experiência recente. Rio de Janeiro: Elsevier e FGV, 2017.

ROMER, C. Fiscal policy in the crisis: lessons and policy implications. Berkeley: University of California, Ap. I6, 20I2. Disponível em: eml.berkeley.edu/ cromer/Lessons\%2ofor\%20 Fiscal\%2oPolicy.pdf. Acesso em: I4 jun. 2017. 
SECRETARIA DE ESTADO DE DESENVOLVIMENTO ECONÔMICO, ENERGIA, INDÚSTRIA E SERVIÇOS (SEDEIS-RJ). “Incentivos fiscais no Estado do Rio de Janeiro" (relatório), 2016.

SHAKESPEARE, W. O mercador de Veneza. Rio de Janeiro: Ediouro, 2005.

SOBRAL, B. "A evidência da estrutura produtiva oca: o estado do Rio de Janeiro como um dos epicentros da desindustrialização nacional”. In MONTEIRO NETO et al. Desenvolvimento regional no Brasil: politicas, estratégias e perspectivas. Brasília: IPEA, 20I7, pp. 398-426. . Metrópole do Rio e projeto nacional. Rio de Janeiro: Garamond, 2013.

TRIBUNAL DE CONTAS DO ESTADO DO RIO DE JANEIRO. Relatório de Auditoria Governamental no Fundo Único de Previdência Social do Estado do Rio de Janeiro. Processo: TCE-RJ n. I08.168-2/16.

VESCOVI, A. P. "Nosso compromisso é com o cumprimento da meta do primário" (entrevista). Conjuntura Econômica, v. 7I, n. 08, pp. I2-7, Rio de Janeiro, ago. 2017. e COSTA, A. C. A. “A ênfase correta”. Estadão. Disponível em: economia.estadao. com.br/noticias/geral,a-enfase-correta,I0000025089. Acesso em: 4 abr. 2016. 